\title{
MODEL COLLABORATIVE GOVERNANCE PADA NAGARI RANCAK DI PROVINSI SUMATERA BARAT
}

\author{
COLLABORATIVE GOVERNANCE MODEL \\ AT NAGARI RANCAK IN WEST SUMATRA PROVINCE
}

\author{
Syamsurizaldi ${ }^{1}$, Annisa Aulia Putri ${ }^{2}$, Suherdian Antoni ${ }^{3}$ \\ Universitas Andalas \\ Email: ${ }^{1}$ syamsurizaldi@gmail.com, ${ }^{2}$ annisaau5@gmail.com, ${ }^{3}$ suherdiaantoni@gmail.com
}

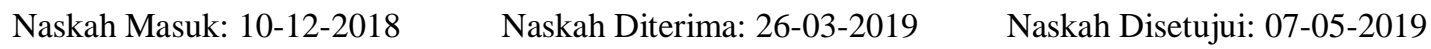

\begin{abstract}
Nagari Rancak is the name for the nagari who won achievements in the village race with the level of West Sumatra Province as an instrument to evaluate the development of the village (nagari) in accordance with Minister of Home Affairs Regulation No. 81 of 2015. Nagari rancak who has achieved various achievements is assumed to have implemented Nagari in accordance with the principles of good local governance and collaborative governance. Based on these phenomena, the objectives of this study are: (1) to describe the profile of the nagari rancak after the enactment of Law Number 6 of 2014 concerning Villages in West Sumatra Province; (2) identify stakeholder actors in the nagari rancak in West Sumatra Province; (3) describe the interaction of stakeholders in collaborative governance in the nagari in West Sumatra Province, and (4) describe the success of collaborative governance in nagari rancak in West Sumatra Province. This study included the type of qualitative research with descriptive analysis. Data sources are stakeholders in the administration of the nagari government as informants and the nagari assessment team is ambitious as triangulation. Data collection through interviews, documentation and observation. The research location was in 9 (nine) nagari which won 1st, 2nd and 3rd place in the provincial nagari competition in 2015, 2106 and 2017. The results of the study found that: (1) Ambiguous Nagari has varied economic potential, has many achievements and variations actors who collaborate in organizing the nagari government. (2) Governance actors collaborating with the nagari government starting from the nagari, sub-district, district, provincial and national levels. The realization of this collaboration was greatly influenced by the existence of self-disclosure and initiatives from Wali Nagari and Alat Nagari. (3) Collaborative actor governance occurs at every stage of the administration of nagari governance, namely planning, budgeting, implementing, monitoring and accountability. However, the most intensive actor interaction at the planning and implementation stages of programs and activities at the nagari level. (6) Collaborative success can be seen from eight indicators according to Goldsmith and Kettl (2009), namely networked structure, commitment to common purpose, trust among participants, governance, access to authority, distributive accountability, informant sharing, and access to resources.
\end{abstract}

Keyword: Collaborative Governance, Local Governance, Nagari Rancak

\begin{abstract}
ABSTRAK
Nagari Rancak adalah sebutan untuk nagari yang meraih prestasi dalam lomba desa berprestasi tingkat Provinsi Sumatera Barat sebagai instrumen untuk mengevaluasi perkembangan desa (nagari) sesuai dengan Peraturan Menteri Dalam Negeri Nomor 81 Tahun 2015. Nagari rancak yang telah meraih berbagai prestasi diasumsikan telah melaksanakan tata kelola pemerintahan nagari sesuai dengan prinsip-prinsip good local governance dan collaborative governance. Berdasarkan fenomena tersebut, maka yang menjadi tujuan dari penelitian ini adalah: (1) mendeskripsikan profil nagari rancak setelah berlakunya UU Nomor 6 Tahun 2014 tentang Desa di Provinsi Sumatera Barat; (2) mengidentifikasi aktor stakeholder pada nagari rancak di Provinsi Sumatera Barat; (3) mendeskripsikan interaksi stakeholder dalam collaborative governance pada
\end{abstract}

Model Collaborative Governance pada Nagari Rancak di Provinsi Sumatera Barat | 99 Syamsurizaldi, Annisa Aulia Putri, Suherdian Antoni 
nagari rancak di Provinsi Sumatera Barat, dan (4) mendeskripsikan keberhasilan collaborative governance pada nagari rancak di Provinsi Sumatera Barat. Penelitian ini termasuk jenis penelitian kualitatif dengan analisis deskriptif. Sumber data yaitu stakeholder penyelenggaraan pemerintahan nagari sebagai informan dan tim penilai nagari rancak sebagai trianggulasi. Pengumpulan data melalui wawancara, dokumentasi serta observasi. Lokasi penelitian pada 9 (sembilan) nagari yang meraih juara 1, 2, dan 3 lomba nagari rancak tingkat provinsi tahun 2015, 2106 dan 2017. Hasil penelitian menemukan bahwa: (1) Nagari rancak memiliki potensi ekonomi bervariasi, memiliki banyak prestasi dan adanya variasi aktor yang berkolaborasi dalam penyelenggaraan pemerintahan nagari. (2) Aktor governance yang berkolaborasi dengan pemerintah nagari mulai dari tingkat nagari, kecamatan, kabupaten, provinsi dan nasional. Terwujudnya kolaborasi ini sangat dipengaruhi adanya keterbukaan diri dan inisiatif dari Wali Nagari dan Perangkat Nagari. (3) Kolaborasi aktor governance terjadi pada setiap tahapan penyelenggaraan pemerintahan nagari yaitu perencanaan, penganggaran, pelaksanaan, pengawasan dan pertanggung jawaban. Namun, interaksi aktor yang paling intensif pada tahapan perencanaan dan pelaksanaan program dan kegiatan di tingkat nagari.

Kata kunci: collaborative governance, pemerintahan nagari, nagari rancak.

\section{PENDAHULUAN}

Governance menunjuk pada pengertian bahwa kekuasaan tidak lagi semata-mata dimiliki atau menjadi urusan pemerintah. Governance menekankan pada pelaksanaan fungsi governing secara bersama-sama oleh pemerintah dan institusi-institusi lainnya, seperti: LSM, perusahaan swasta, maupun warga negara. Meskipun perspektif governance mengimplikasikan terjadinya pengurangan peran pemerintah, tetapi pemerintah sebagai institusi tidak bisa ditinggalkan begitu saja (Malau, 2013). Perspektif governance pada dasarnya merupakan proses pembuatan kebijakan, dimana semua prosesnya melibatkan unsur pemerintahan, yaitu pemerintah, masyarakat, dan swasta. kesemuanya memiliki peran yang sama-sama penting. Negara berperan menciptakan suasana sosial dan politik yang kondusif. Sektor swasta berperan menciptakan lapangan pekerjaan dan pendapatan. Sedangkan masyarakat berperan memfasilitasi interaksi sosial dan politik yang memadai bagi mobilisasi individu atau kelompokkelompok masyarakat untuk berpartisipasi dalam aktivitas ekonomi, politik, dan sosial (Kurniawan T., 2009).

Pemerintah (Government) dalam bahasa Inggris diartikan sebagai "The authoritative direction and
administration of the affairs of
men/women in nation, state, city, etc.(Sedarmayanti, 2004). Sedangkan kepemerintahan, atau dalam Bahasa Inggris governance yaitu the act, fact manner of governing (Sedarmayanti, 2004). Dengan demikian, Governance adalah suatu proses, sebagaimana diungkapkan oleh Koiman (2008), governance merupakan serangkaian proses interaksi sosial politik antara pemerintah dengan masyarakat dalam berbagai bidang yang berkaitan dengan kepentingan masyarakat dan intervensi pemerintah atas kepentingan-kepentingan tersebut. Istilah governance tidak hanya berarti kepemerintahan sebagai suatu kegiatan, tetapi juga mengandung arti pengurusan, pengelolaan, pengarahan, pembinaan penyelenggaraan dan juga bisa diartikan pemerintahan (Sedarmayanti, 2004). Dalam Governance, pemerintah bukan menjadi penentu, tapi merupakan salah satu aktor. Pemerintah merupakan penggerak yang mampu memfasilitasi masyarakat dan privat aktif dalam penyelenggaraan pemerintahan. Dari perspektif sejarah, format penyelenggaraan pemerintahan nagari yang ideal (Syamsurizaldi, 2012) sebenarnya telah sejalan dengan konsep 
dan prinsip collaborative governance, dimana nagari bukan hanya entitas pemeirntah tetapi juga melibatkan masyarakat adat dan dunia usaha, yang tercermin dari rasa memiliki nagari dan rasa banagari.

Koiman mendefinisikan Governance sebagai serangkaian proses interaksi sosial politik antara pemerintah dengan masyarakat dalam berbagai bidang yang berkaitan dengan kepentingan masyarakat dan intervensi pemerintah atas kepentingan-kepentingan tersebut. Tata pemerintahan mencakup seluruh mekanisme, proses, dan lembagalembaga dimana warga dan kelompokkelompok masyarakat mengutarakan kepentingan mereka, menggunakan hak hukum, memenuhi kewajiban dan menjembatani perbedaan-perbedaan diantara mereka.

Format interaksi antara pemerintah dengan masyarakat mengalami pergeseran dari yang awalnya "warga negara" atau pemerintahan (government) sebagai paradigma klasik pemerintahan negara dan penyelengaraan pembangunan maupun pelayanan publik menjadi format baru yang dikenal dengan istilah Governance. Konsep Governance yang dikemukakan Koiman (2008) menekankan pada pemecahan masalah sosial dan menciptakan interaksi antara pemerintah, masyarakat, dan swasta.Konsep utama dari interactive governance menurut Koiman (2008) adalah The whole of interaction taken to solve societal problem and to create societal opportunities: including the formulation and aplication of principles guiding those interaction and care for institution that enable and control them

Dalam kaitan dengan proses desentralisasi yang sudah berjalan di Indonesia, isu Governance yang didiskusikan menjadi lebih terfokus pada Governance di tingkat lokal (Sumarto, 2003). Dalam mendukung Governance di tingkat lokal, pemerintah mengeluarkan UU Nomor 6 Tahun 2014 tentang Desa. UU ini mengembangkan paradigma dan konsep baru tata kelola desa secara nasional. Desa bukan lagi menjadi terbelakang, namun merupakan etalase nagara. UU Desa mengangkat hak dan kedaulatan desa yang selama ini terpinggirkan. Undang-undang ini mulai efektif dilaksanakan pada tahun 2015, dimana diatur dengan tegas dan jelas tentang kewenangan desa dalam tata kelola penyelenggaraan pemerintahan desa;

Salah satu kebijakan pemerintah dalam undang-undang desa untuk mendorong peningkatan kemajuan desa adalah pengalokasikan Dana Desa (DD) yang bersumber dari APBN. Kemudian Pemerintah Daerah (Kabupaten/Kota) diwajibkan pula mengalokasikan Alokasi Dana Desa (ADD) dan Bagi Hasil Pajak dan Retribusi Daerah (BHPRD) yang bersumber dari APBD Kabupaten/Kota sejak tahun 2015. Hal ini berimplikasi terhadap pentingnya tata kelola pemerintahan desa sesuai dengan prinsipprinsip goodlocal governance dan collaborative governance. Peningkatan sumber keuangan desa masih dominan dialokasikan untuk pembangunan fisik dan minim untuk kegiatan pemberdayaan (Syamsurizaldi, Putri, Antoni 2018). Peningkatan nilai publik (public value) melalui kolaborasi dalam penyelenggaraan pemerintahan desa atau nagari menarik dikaji (Putri, Ariany dan Syamsurizaldi; 2019). Salah satu strategi baru dari pemerintahan disebut sebagai pemerintahan kolaboratif atau Collaborative Governance. Bentuk dari governance yang melibatkan berbagai 
stakeholder atau pemangku kepentingan secara bersamaan di dalam sebuah forum dengan aparatur pemerintah untuk membuat keputusan bersama (Ansell dan Alison, 2007 : 543). Anshell dan Gash menjelaskan collaborative governance adalah suatu pengaturan pemerintahan dimana satu atau lebih lembaga publik secara langsung melibatkan para pemangku kepentingan non-pemerintah dalam proses pengambilan keputusan kolektif yang bersifat formal, berorientasi pada konsensus, deliberatif yang bertujuan untuk membuat dan menerapkan kebijakan publik serta mengelola program ataupun aset publik (Afful-Koomson dan Kwabena, 2013:13).

Untuk melihat kemajuan dan perkembangan desa, Kementerian Dalam Negeri melaksanakan perlombaan desa melalui Peraturan Menteri Dalam Negeri Nomor 13 Tahun 2007 tentang Perlombaan Desa dan Kelurahan, yang kemudian diganti dengan Peraturan Menteri Dalam Negeri Nomor 81 Tahun 2015 tentang Evaluasi Perkembangan Desa dan Kelurahan. Penyelenggaraan perlombaan desa dan kelurahan dilakukan mengevaluasi dan menilai perkembangan pembangunan atas usaha pemerintah daerah bersama dengan masyarakat desa dan kelurahan yang berkaitan.Lomba desa di Provinsi Sumatera Barat disebut dengan istilah Lomba Nagari Rancak, yang secara teknis pelaksanaanya sama dengan lomba desa secara nasional.

Untuk percepatan perkembangan desa pada desa juara dan desa sekitarnya pemerintah provinsi telah merencanakan khusus bagi desa-desa juara lomba desa, dijadikan pilot project desa mandiri yang pembinaannya melibatkan seluruh OPD sehingga kegiatannya terkoordinir (Ahfan, 2015). Desa yang menjadi pemenang lomba desa akan dijadikan percontohan bagi desa lain dalam pelaksanaan pemerintahannya.Pemenang lomba desa tingkat provinsi sumatera barat disebut dengan "nagari rancak". Kata "rancak" mengandung makna bahwa penyelenggaraan pemerintahan nagari yang baik dan maju. Dalam perspektif administrasi publik, penyelenggaraan pemerintahan nagari yang baik dapat disebut dengan tata kelola pemerintahan yang baik atau good governance. Untuk mewujudkan tata kelola pemerintahan yang baik, diperlukan interaksi berbagai aktor stakeholder. Salah satu model interaksi aktor stakeholder yaitu collaborative governance. Kolaborasi menurut Hanida (2017) adalah kerjasama dan hubungan antar organisasi yang disepakati bersama-sama melalui proses komunikasi. Sementara Benton (2013)) menyatakan bahwa kolaborasi dalam penyediaan layanan publik yang melibatkan dua atau lebih tingkatan pemerintahan (nasional, regional, daerah dan lokal) tidak jarang terjadi kolaborasi harus dilakukan dengan berbagai cara atau strategis.

Keberhasilan sebuah nagari meriah prediket sebagai nagari rancak melalui proses yang cukup panjang dan diduga keberhasilan tersebut merupakan hasil dari kolaborasi banyak aktor stakeholder di nagari. Menurut Goldsmith dan Kettl, terdapat hal penting yang bisa dijadikan sebagai kriteria keberhasilan collaborative governance, yaitu networked structure, commitmen to a common purpose, trust among the participants, governance, access to authority, distributive accountability/responsibility, informan sharing, dan access to resources (Goldsmith dan Donald, 2009). Dalam penelitian ini dibangun asumsi bahwa nagari rancak telah mengimplementasikan 
tata kelola pemerintahan yang baik dengan melibatkan banyak aktor stakeholder berkolaborasi dalam penyelenggaraan pemerintahan nagari. Berdasarkan fenomena tersebut diatas, maka peneliti tertarik untuk mengkaji Model Collaborative Governance Pada Nagari Rancak di Provinsi Sumatera Barat. Adapun tujuan penelitian ini adalah: (1) menggambarkan profil nagari rancak; (2) mengidentifikasi aktor stakeholder pada nagari rancak; (3) menggambarkan interaksi stakeholder dalam collaborative governance pada nagari rancak, dan (4) sejauhmana keberhasilan collaborative governance pada nagari rancak di Provinsi Sumatera Barat.

\section{METODOLOGI}

Penelitian ini menggunakan metode penelitian deskriptif dengan pendekatan kualitatif. Untuk melihat bagaimana model collaborative governance pada nagari rancak di Provinsi Sumatera Barat setelah berlakunya UU Nomor 6 tahun 2014 tentang Desa. Untuk mendapatkan hasil yang diharapkan maka peneliti menggunakan pendekatan kualitatif. Penelitian kualitatif menurut (Strauss Corbin:1990:17) adalah qualitatif research we mean any kind of research that produces finding not arrived at by means of statistical procedures or other means quantification". Artinya bahwa berdasarkan permasalahan penelitian yang telah dikemukakan diatas dimana data yang dibutuhkan lebih bersifat informasi yang komprehensif dan luas, maka penelitian ini cocok menggunakan pendekatan kualitatif. Penelitian kualitatif juga mempunyai makna penelitian sementara yang berkembang di lapangan dan menganalisis data secara induksi (Moleong, 2000: 3). Pemilihan informan dalam penelitian ini menggunakan teknik purposive sampling. Dengan demikian informan dalam penelitian ini adalah pihak yang terkait dan mengetahui permasalahan penelitian, seperti pada level pemerintah nagari, maka yang menjadi informan yaitu 7 (tujuh) orang Wali Nagari, 2 (dua) orang Sekretaris Nagari, dan perangkat nagari yang relevan dengan permasalahan penelitian. Data dikumpulkan melalui dokumentasi dan wawancara mendalam (indepth interview).

Selanjutnya, untuk memperoleh keabsahan data secara maksimal peneliti menggunakan teknik triangulasi sumber (informasi). Triangulasi adalah teknik pemeriksaan keabsahan data yang memanfaatkan sesuatu di luar data itu untuk keperluan pengecekan atau sebagai pembanding terhadap data itu (Moleong, 2001:178). Triangulasi sumber berarti membandingkan dan mengecek balik derajat kepercayaan suatu informasi yang diperoleh melalui waktu dan alat yang berbeda dalam metode kualitatif (Patton dalam Moleong, 2002: 178), yang dapat dicapai dengan membandingkan pendapat antara satu informan dengan informan lain. Trianggulasi sumber dilakukan terhadap Camat, Kepala Dinas Pemberdayaan Masyarakat Desa Kabupaten dan Provinsi. Penelitian difokuskan pada nagari-nagari yang meraih Juara 1, 2 dan 3 lomba nagari berprestasi tingkat Provinsi Sumatera Barat tahun 2015-2017 sebagaimana terlihat pada Tabel 1: 
Tabel 1. Juara Lomba Nagari Berprestasi Tingkat Provinsi Sumatera Barat Tahun 2015-2017

\begin{tabular}{cclll}
\hline Tahun & Juara & & \multicolumn{1}{c}{ Kecamatan } & Kabupaten \\
\hline 2015 & I & Sungayang & Sungayang & Tanah Datar \\
& II & Padang Tarok & Baso & Agam \\
& III & Koto Tinggi & Koto Besar & Dharmasraya \\
2016 & I & Batu Bulek & Lintau Buo Utara & Tanah Datar \\
& II & Palaluar & Koto VII & Sijunjung \\
& III & Koto Ranah & Koto Besar & Dharmasraya \\
& I & Sungai Nyalo IV Koto Mudiak & Batang Kapas & Pesisir Selatan \\
& II & Manggopoh & Lubuk Basung & Agam \\
& III & Lubuak Jantan & Lintau Buo Utara & Tanah Datar \\
\hline
\end{tabular}

Sumber: Dinas Pemberdayaan Masyarakat dan Desa/Nagari Provinsi Sumatera Barat (2018)

\section{HASIL DAN PEMBAHASAN}

Profil Nagari Rancak di Provinsi Sumatera Barat

Penelitian Model Collaborative

Governance Pada Nagari Rancak di Provinsi Sumatera Barat dilakukan pada sembilan Nagari, yaitu Nagari yang memenangkan perlombaan Nagari

Tabel 2. Profil Nagari Lokasi Penelitian Dari Aspek Potensi dan Sumberdaya

\begin{tabular}{|c|c|c|c|c|c|c|}
\hline \multirow[b]{2}{*}{ No. } & \multirow[b]{2}{*}{ Nagari } & \multicolumn{5}{|c|}{ Potensi dan Sumberdaya Nagari } \\
\hline & & $\begin{array}{l}\text { Luas } \\
\text { Wilayah } \\
(\mathrm{Km} 2)\end{array}$ & $\begin{array}{l}\text { Jumlah } \\
\text { Penduduk } \\
\text { (Jiwa) }\end{array}$ & $\begin{array}{l}\text { Jumlah } \\
\text { Jorong }\end{array}$ & $\begin{array}{l}\text { Sektor Utama } \\
\text { Perekonomian }\end{array}$ & $\begin{array}{c}\text { Sumber Mata } \\
\text { Pencaharian } \\
\text { Utama } \\
\text { Penduduk }\end{array}$ \\
\hline 1. & Sungayang & 8,00 & 3.064 & 3 & $\begin{array}{l}\text { Pertanian } \\
\text { (sawah) }\end{array}$ & $\begin{array}{l}\text { Pertanian dan } \\
\text { perkebunan }\end{array}$ \\
\hline 2. & $\begin{array}{l}\text { Padang } \\
\text { Tarok }\end{array}$ & 16,34 & 7.195 & 7 & $\begin{array}{l}\text { Pertanian } \\
\text { (sawah) }\end{array}$ & $\begin{array}{l}\text { Pertanian dan } \\
\text { perdagangan }\end{array}$ \\
\hline 3. & Koto Tinggi & 24,80 & 3.010 & 4 & $\begin{array}{l}\text { Pertanian } \\
\text { (perkebunan) }\end{array}$ & $\begin{array}{l}\text { Perkebunan } \\
\text { kelapa sawit }\end{array}$ \\
\hline 4. & Batu Bulek & 3,50 & 8.212 & 9 & $\begin{array}{l}\text { Pertanian } \\
\text { Pariwisata, } \\
\text { pertanian, } \\
\text { industri }\end{array}$ & Pertanian \\
\hline 5. & Palaluar & 143,90 & 3.260 & 5 & $\begin{array}{l}\text { Pertanian dan } \\
\text { perkebunan }\end{array}$ & $\begin{array}{l}\text { Pertanian dan } \\
\text { perkebunan }\end{array}$ \\
\hline 6. & Koto Ranah & 35,07 & 4.574 & 4 & $\begin{array}{l}\text { Pertanian } \\
\text { (perkebunan) }\end{array}$ & $\begin{array}{l}\text { Perkebunan } \\
\text { kelapa sawit } \\
\text { dan karet }\end{array}$ \\
\hline 7. & $\begin{array}{l}\text { Sungai Nyalo } \\
\text { IV Koto } \\
\text { Mudiak }\end{array}$ & 10,00 & 3.064 & 3 & Pertanian & $\begin{array}{l}\text { Bertani, } \\
\text { berkebun }\end{array}$ \\
\hline 8. & Manggopoh & 118,20 & 22.365 & 8 & $\begin{array}{l}\text { Perkebunan } \\
\text { sawit }\end{array}$ & $\begin{array}{l}\text { Pertanian, } \\
\text { Perkebunan } \\
\text { dan Perikanan } \\
\text { dan Jasa. }\end{array}$ \\
\hline 9. & $\begin{array}{l}\text { Lubuak } \\
\text { Jantan }\end{array}$ & 79,39 & 9.732 & 11 & $\begin{array}{l}\text { Pengasapan } \\
\text { ikan, pupuk } \\
\text { pertanian }\end{array}$ & Pertanian \\
\hline
\end{tabular}

Sumber: Olahan Peneliti (2018)

104 | Jurnal Pembangunan Nagari | Volume 4 Nomor 1 Edisi Juni 2019 : 99- 121

Berprestasi tingkat Provinsi Tahun 20152017. Untuk dapat memenangkan perlombaan, Pemerintah Nagari harus mampu berinteraksi dengan masyarakat maupun privat yang ada di Nagari. Profil Nagari Rancak tersebut bisa dilihat pada

Tabel 2: 
Berdasarkan Tabel 2 terlihat bahwa Nagari yang menjadi lokasi penelitian merupakan kawasan pedesaan dengan sektor ekonomi utama yaitu pertanian. Nagari Sungayang, Padang Tarok, Batu Bulek, Lubuk Jantan, Sungai Nyalo IV Koto Mudiak dan Lubuk Jantan memiliki komoditi pertanian utamanya adalah padi, plawija dan perkebunan karet rakyat. Sedangkan Nagari Koto Ranah dan Koto Tinggi merupakan Nagari yang berasal dari Eks Desa Unit Transmigrasi Sitiung, dengan komoditi pertanian utamanya adalah perkebunan kelapa sawit. Kemudian Nagari Manggopoh memiliki karakteristik pertanian yang lebih lengkap, yaitu pertanian padi, plawija dan perikanan dengan sumber air dari Danau Maninjau. Nagari Manggopoh juga memiliki potensi ekonomi di sektor jasa dan perdagangan karena berada di persimpangan ruas jalan provinsi yang menghubungkan Kota Lubuk Basung dengan Kabupaten Padang Pariaman dan Kabupaten Pasaman Barat. Perbedaan sektor utama perekonomian masyarakat ini berimplikasi terhadap adanya variasi aktor governance yang berkolaborasi dalam penyelenggaraan pemerintahan nagari.

\section{Identifikasi Aktor Stakeholder}

\section{Collaborative Governance Pada Nagari}

\section{Rancak di Provinsi Sumatera Barat}

Tabel 3. Identifikasi Aktor Government Society Pada Nagari Rancak di Provinsi Sumatera Barat

\begin{tabular}{|c|c|c|c|c|c|c|}
\hline \multirow{2}{*}{ No } & \multirow{2}{*}{ Nagari } & \multicolumn{5}{|c|}{ Aktor Government Society Berdasarkan Tingkatan Administrasi Pemerintahan } \\
\hline & & Nagari & Kecamatan & Kabupaten & Provinsi & Nasional \\
\hline 1. & Sungayang & $\begin{array}{l}\text { Pemerintah } \\
\text { Nagari, BPRN, } \\
\text { LPMN }\end{array}$ & Camat & $\begin{array}{l}\text { Pemerintah } \\
\text { Kabupaten }\end{array}$ & $\begin{array}{l}\text { Pemerintah } \\
\text { Provinsi }\end{array}$ & Kemendes PDTT \\
\hline 2. & Padang Tarok & $\begin{array}{l}\text { Pemnag, } \\
\text { Bamus, KAN, } \\
\text { LPM, MUI, } \\
\text { Bundo } \\
\text { kanduang, LPHN }\end{array}$ & Camat & $\begin{array}{l}\text { Pemerintah } \\
\text { Kabupaten, } \\
\text { Anggota DPRD } \\
\text { Kabupaten }\end{array}$ & $\begin{array}{l}\text { Anggota DPRD } \\
\text { Provinsi (Partai } \\
\text { Demokrat) }\end{array}$ & \\
\hline 3. & Koto Tinggi & $\begin{array}{l}\text { Pemerintah } \\
\text { Nagari, LPMN, } \\
\text { FORKAN, }\end{array}$ & Camat & $\begin{array}{l}\text { Pemerintah } \\
\text { Kabupaten, Dinas } \\
\text { Pertanian dan }\end{array}$ & $\begin{array}{l}\text { Widiatmo } \\
\text { Anggota DPRD } \\
\text { Provinsi(Widatmo }\end{array}$ & $\begin{array}{l}\text { Hermanto } \\
\text { Anggota DPR RI } \\
\text { (Hermanto dari }\end{array}$ \\
\hline
\end{tabular}

$\begin{array}{lc}\text { Collaborative } & \text { governance } \\ \text { merupakan suatu } & \text { pengaturan } \\ \text { pemerintahan dimana satu atau lebih } & \\ \text { lembaga publik secara langsung }\end{array}$ melibatkan pemangku kepentingan nonpemerintah dalam proses pengambilan keputusan kolektif yang bersifat formal, berorientasi pada konsensus, deliberatif menerapkan kebijakan publik serta mengelola program ataupun aset publik. Berdasarkan pengertian tersebut, terlihat bahwa terdapat pola interaksi antara pemerintah dengan stakeholder nonpemerintah. Secara umum terdapat tiga komponen yang saling berinteraksi dalam governance, yaitu pemerintah (government society), dunia usaha (business society) dan masyarakat (community society). Untuk menganalisis lebih dalam proses collaborative governance pada nagari rancak di Provinsi Sumatera Barat, peneliti terlebih dahulu mengidentifikasi aktor-aktor yang pemerintahan nagari rancak yang menjadi lokus penelitian.

Aktor goverment society yang berkolaborasi dalam penyelenggaraan pemerintahan nagari seperti pada Tabel 3: yang bertujuan untuk membuat dan terlibat dalam penyelenggaraan 


\begin{tabular}{|c|c|c|c|c|c|c|}
\hline & & & & $\begin{array}{l}\text { Kehutanan } \\
\text { Kabupaten } \\
\text { Dharmasraya }\end{array}$ & dari PKS) & PKS) \\
\hline 4. & Batu Bulek & $\begin{array}{l}\text { Pemerintah } \\
\text { Nagari, BPRN }\end{array}$ & Camat & $\begin{array}{l}\text { Pemerintah } \\
\text { Kabupaten } \\
\text { Anggota DPRD } \\
\text { Kabupaten }\end{array}$ & & $\begin{array}{l}\text { Kementerian } \\
\text { Kominfo RI }\end{array}$ \\
\hline 5. & Palaluar & $\begin{array}{l}\text { Pemerintah } \\
\text { Nagari, BPN }\end{array}$ & $\begin{array}{l}\text { Camat, } \\
\text { Forkompim } \\
\text { Kecamatan }\end{array}$ & $\begin{array}{l}\text { Dinas PMN, Dinas } \\
\text { Pendidikan dan } \\
\text { Kebudayaan }\end{array}$ & & \\
\hline 6. & Koto Ranah & $\begin{array}{l}\text { Pemerintah } \\
\text { Nagari, Bamus }\end{array}$ & $\begin{array}{l}\text { Camat, UPT } \\
\text { Tingkat } \\
\text { Kecamatan } \\
\text { (Puskesmas, } \\
\text { UPTD } \\
\text { Pendidikan) }\end{array}$ & $\begin{array}{l}\text { Dinas PMD } \\
\text { Kabupaten, Dinas } \\
\text { Pertanian, Dinas } \\
\text { PUPR, Dinas } \\
\text { Kopperindag, Dinas } \\
\text { Pendidikan, Dinas } \\
\text { Kesehatan, Dinas } \\
\text { Dukcapil }\end{array}$ & $\begin{array}{l}\text { Dinas PU Provinsi, } \\
\text { Dinas Perkebunan } \\
\text { Provinsi }\end{array}$ & $\begin{array}{l}\text { Balai Wilayah } \\
\text { Sungai } \\
\text { Sumatera V } \\
\text { (BWSS V) } \\
\text { Kementerian } \\
\text { PUPR, Dirjen } \\
\text { Perkebunan } \\
\text { Kementerian } \\
\text { Pertanian }\end{array}$ \\
\hline 7. & $\begin{array}{l}\text { Sungai Nyalo } \\
\text { IV Koto } \\
\text { Mudiak }\end{array}$ & $\begin{array}{l}\text { Pemerintah } \\
\text { Nagari, Bamus }\end{array}$ & Camat & $\begin{array}{l}\text { Pemerintah } \\
\text { Kabupaten }\end{array}$ & $\begin{array}{l}\text { Pemerintah } \\
\text { Provinsi }\end{array}$ & \\
\hline 8. & Manggopoh & $\begin{array}{l}\text { Pemerintah } \\
\text { Nagari, Bamus }\end{array}$ & Camat & $\begin{array}{l}\text { Pemerintah } \\
\text { Kabupaten }\end{array}$ & $\begin{array}{l}\text { Pemerintah } \\
\text { Provinsi }\end{array}$ & DPR RI \\
\hline 9. & Lubuak Jantan & $\begin{array}{l}\text { Pemerintah } \\
\text { Nagari, BPRN }\end{array}$ & Camat & $\begin{array}{l}\text { Dinas PMD } \\
\text { Kabupaten Tanah } \\
\text { Datar }\end{array}$ & & \\
\hline
\end{tabular}

Sumber: Olahan Peneliti (2018)

Berdasarkan Tabel 5, terlihat bahwa aktor government society yang berkolaborasi dengan pemerintah nagari mulai dari tingkat nagari, kecamatan, kabupaten, provinsi dan nasional. Secara umum, aktor government soceity pada masing-masing nagari relatif sama yaitu Pemerintah Nagari, Bamus/BPRN/BPN, Camat dan Forum Pimpinan Pemerintah Kecamatan (Kapolsek dan Danramil), OPD tingkat Kabupaten terutama Dinas Pemberdayaan Masyarakat dan Desa dan OPD teknis yang memiliki program kerja yang relevan dengan potensi dan prioritas pembangunan nagari, Pemerintah Provinsi terutama Dinas Pemberdayaan Masyarakat dan Desa dan OPD teknis yang memiliki program relevan dengan prioritas pembangunan nagari, dan Kementerian/Lembaga di tingkat pusat. Misalnya, Pemerintah Nagari Batu Bulek berkolaborasi dengan Kementerian
Komunikasi dan Informasi, dalam penyediaan Wifi gratis bagi masyarakat Nagari Batu Bulek dan Pemerintah Nagari Koto Ranah dengan Kementerian PUPR melalui Balai Sungai Sumatera Wilayah V dalam pelaksanaan pembangunan Embung Koto Ranah.

Disamping berkolaborasi dengan jajaran pemerintah (eksekutif), ditemukan pula bahwa pemerintah nagari juga berkolaborasi dengan jajaran legislatif secara individual yaitu dengan DPRD tingkat Kabupaten, DPRD Provinsi dan DPR-RI. Di Nagari Padang Tarok, Pemerintah Nagari berkolaborasi dengan anggota DPRD Kabupaten dan Provinsi yang berasal dari nagari tersebut dan berada dalam satu partai yaitu Partai Demokrat. Anggota DPRD tersebut merupakan bagian dari Ikatan Keluarga Padang Tarok (IKPT). Pemerintah Nagari Koto Tinggi berkolaborasi dengan 
Anggota DPRD Provinsi Sumatera Barat (Widiatmo) dan Anggota DPR RI (Hermanto) yang berasal dari Partai Keadilan Sejahtera. Interaksi dan kolaborasi yang dilakukan yang dilakukan dalam bentuk melaksanakan program pemerintahan yang terkait. Kemudian Pemerintah Nagari Batu Bulek bekerja sama beberapa anggota DPRD Kabupaten melalui pengelolaan dana pokok-pokok pikiran yang dialokasikan dalam bentuk Bantuan Keuangan bersifat Khusus (BKK) pada APB Nagari Batu Bulek. Pelaksanaan kegiatannya menjadi keweangan penuh dari pemerintahan nagari.

$\begin{array}{ll}\text { Selanjutnya aktor business } & \text { society } \\ \text { yang berkolaborasi } & \text { dalam } \\ \text { penyelenggaraan pemerintahan } & \text { nagari } \\ \text { seperti pada Tabel } 4 . & \end{array}$

Tabel 4. Identifikasi Aktor Business Society Pada Nagari Rancak di Provinsi Sumatera Barat

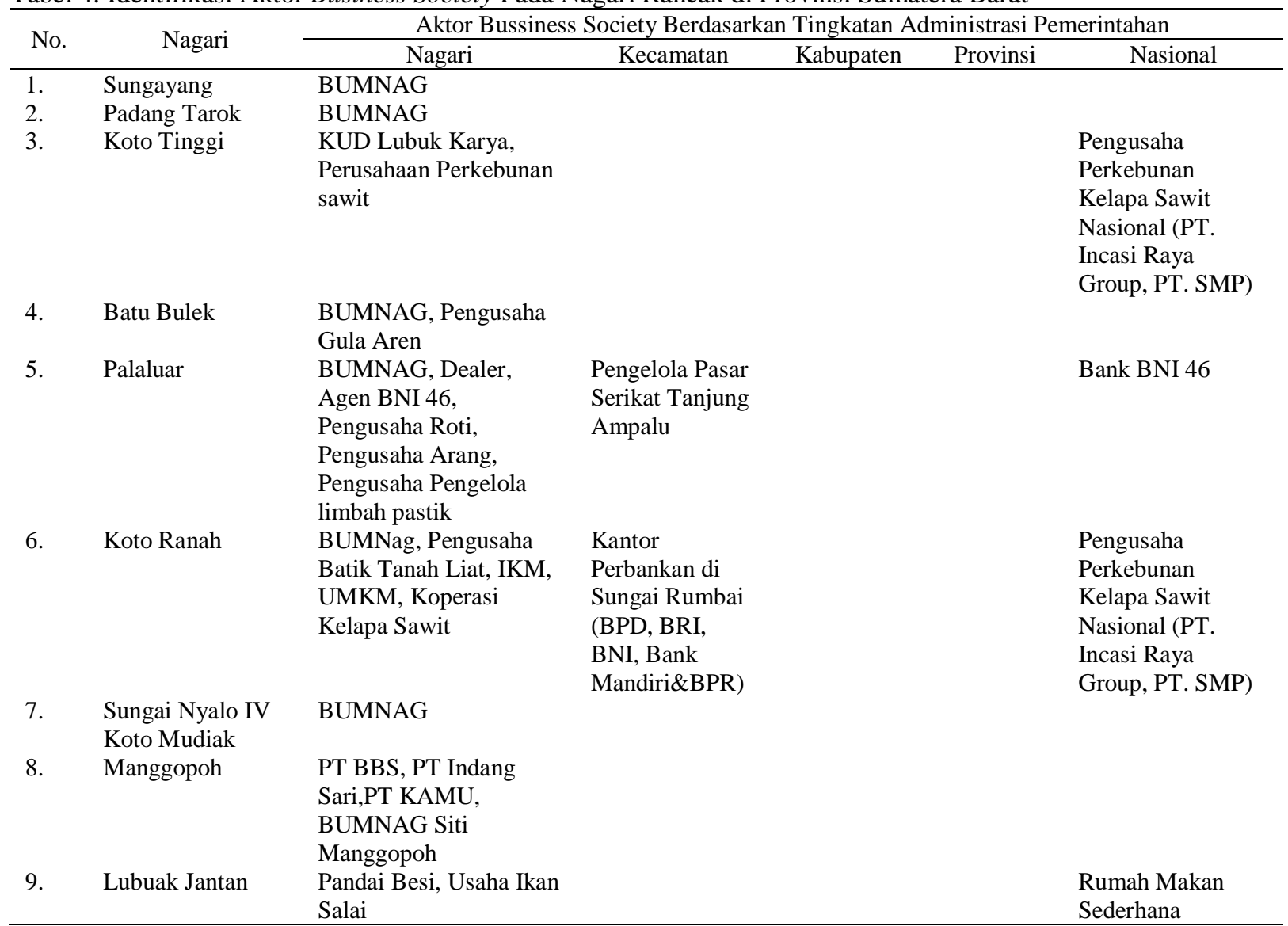

Sumber: Olahan Peneliti (2018)

Dalam collaborative governance, aktor yang berkolaborasi juga ditemukan berasal dari business society sebagaimana dapat dilihat pada Tabel 4. BUMNag menjadi aktor penting dan intensif berkolaborasi dengan pemerintah nagari yang disebabkan setiap nagari wajib memiliki BUMNag yang diharapkan dapat meningkatkan aktivitas ekonomi masyarakat, membuka lapangan kerja baru serta memberikan kontribusi terhadap pendapatan asli nagari. Berdasarkan wawancara dan observasi, juga ditemukan beberapa aktor business society dimana yang dominan adalah perusahaan perkebunan. Dari 9 nagari 
lokus teradapat 3 nagari yang memiliki investasi perkebunan kelapa sawit yaitu Koto Tinggi, Koto Ranah dan Manggopoh. Pemerintah Nagari Koto Tinggi bekerja sama dengan perusahaan perkebunan kelapa sawit dan Koperasi Unit Desa (KUD) Lubuk Karya yang anggotanya sebagian besar merupakan penduduk nagari koto tinggi dalam mengelola aset nagari, yaitu tanah kas desa berupa kebun kelapa sawit seluas 50 Ha.

Selain itu, perusahaan-perusahaan perkebunan juga menyalurkan CSR untuk pembangunan fisik di nagari, seperti untuk pembangunan MDA dan jembatan. Hal yang sama juga ditemukan di Nagari Koto Ranah, dimana perusahaan perkebunan kelapa sawit menyalurkan CSR untuk pembangunan pagar lapangan bola kaki yang dikerjakan secara gotong royong dengan masyarakat. Sedangkan pada Nagari Manggopoh perusahaan perkebunan kelapa sawit memberikan fee kepada Kerapatan Adat Nagari atas pengelolaan tanah ulayat dan dana tersebut digunakan untuk pembangunan nagari, salah satu bentuknya adalah pembangunan kantor wali nagari manggopoh yang cukup megah.

Kemudian di Nagari Batu Bulek, pemerintah nagari berkolaborasi dengan pengusaha gula aren dalam mengembangkan industri gula aren sebagai sumber mata pencaharian beberapa penduduk nagari. Bahan baku gula aren berasal dari pohon enau dan tebu yang berlokasi di Puncak Pato. Untuk Nagari Palaluar, business society yang berkolaborasi dengan pemerintahan nagari melalui BUMNag adalah dealer sepeda motor dalam melaksanakan program arisan sepeda motor, BNI 46, pengusaha roti, pengusaha arang dan pengusaha pengolah limbah pastik.
Interaksi dan kolaborasi dengan business society ini memberikan dampak berupa lapangan kerja baru yang dapat meningkatkan pendapatan masyarakat nagari.

Di Nagari Koto Ranah, aktor business society yang berkolaborasi selain pengusaha kelapa sawit adalah Pengusaha UMKM Batik Tanah Liat yang ikut menggiatkan perekonomian masyarakat nagari dengan memanfaatkan produk unggulan nagari, yaitu batik tanah liat. Para pengusaha batik berpartisipasi dalam memberikan edukasi kepada pengusaha industri rumah tangga secara gratis. Pengusaha batik lokal juga menjadi narasumber gratis bagi kelompok masyarakat (UMKM atau IKM) dengan bidang usaha yang berbeda dengan tujuan untuk melakukan transfer knowledge bidang pengembangan kewirausahaan melalui kegiatan pelatihan dan pemberdayaan yang difasilitasi oleh pemerintahan nagari Koto Ranah bersama lembaga terkait di tingkat nagari.

Di Nagari Manggopoh dalam pemberdayaan petani, bentuk kerja sama dengan beberapa perusahaan perkebunan kelapa sawit yaitu pemberian bantuan bibit kakao, bibit durian dan tanaman buah lainnya, untuk mengurangi minat masyarakat dalam menanam kelapa sawit. Hal ini dipelopori oleh Wali Nagari untuk menjaga ekologi dan kelestarian lingkungan. Upaya menjaga ekologi dan kelestarian lingkungan juga dilakukan oleh Wali Nagari Koto Tinggi dengan membuat peraturan nagari yang mewajibkan penganten baru sebelum menikah untuk menanam minimal dua batang pohon buah di pekarangan rumah. Berdasarkan Tabel 5, dapat disimpulkan bahwa untuk dapat menjalankan roda pemerintahan, dan meningkatkan perekonomian masyarakat, pemerintah 
nagari telah melakukan kerjasama dengan aktor business society, yang memiliki sumber daya seperti keahlian dalam berwirausaha, jejaring dan juga modal dalam melakukan pembinaan terhadap aktiftas ekonomi masyarakat dan memberikan dukungan dalam pembangunan fisik di nagari.

Aktor ketiga dalam collaborative governance adalah community society.
Community atau komunitas adalah sekelompok orang yang peduli terhadap suatu ide dan gagasan dan konsisten memperjuangkan ide dan gagasan tersebut, termasuk salah satu caranya adalah melalui kolaborasi dengan jajaran pemerintahan nagari. Identifikasi aktor community society pada sembilan Nagari Rancak seperti pada Tabel 5.

Tabel 5. Identifikasi Aktor Community Society Pada Nagari Rancak di Provinsi Sumatera Barat

\begin{tabular}{|c|c|c|c|c|c|c|}
\hline \multirow{2}{*}{ No. } & \multirow{2}{*}{ Nagari } & \multicolumn{5}{|c|}{ Aktor Community Society Berdasarkan Tingkatan Administrasi Pemerintahan } \\
\hline & & Nagari & Kecamatan & Kabupaten & Provinsi & Nasional \\
\hline 1. & Sungayang & TP PKK, Karang & Pendamping & TA P3MD & Nagari & Perantau \\
\hline & & Taruna & Desa & & Development & Warga \\
\hline & & & & & Centre (NDC) & $\begin{array}{l}\text { Sungayang } \\
\text { (PWS) }\end{array}$ \\
\hline 2. & Padang Tarok & $\begin{array}{l}\text { TP-PKK, KAN, } \\
\text { Karang Taruna }\end{array}$ & $\begin{array}{l}\text { Pendamping } \\
\text { Desa }\end{array}$ & TA P3MD & & IKPT \\
\hline 3. & Koto Tinggi & $\begin{array}{l}\text { FORKAN, LSM, } \\
\text { Kelompok Wanita } \\
\text { Tani }\end{array}$ & $\begin{array}{l}\text { KAN Koto } \\
\text { Besar }\end{array}$ & TA P3MD & & \\
\hline 4. & Batu Bulek & $\begin{array}{l}\text { KAN, LPM Nagari, } \\
\text { Pengurus Majlis } \\
\text { Ta'lim, Pekerja } \\
\text { Sosial Masyarakat }\end{array}$ & $\begin{array}{l}\text { Pendamping } \\
\text { Desa }\end{array}$ & TA P3MD & $\begin{array}{l}\text { Perguruan } \\
\text { Tinggi (PNP) }\end{array}$ & Perantau IKBB \\
\hline 5. & Palaluar & $\begin{array}{l}\text { KAN, Ninik Mamak, } \\
\text { Pemuda, } \\
\text { Kelompokk Seni } \\
\text { Budaya, Bundo } \\
\text { Kanduang }\end{array}$ & $\begin{array}{l}\text { Pendamping } \\
\text { Desa }\end{array}$ & TA P3MD & & \\
\hline 6. & Koto Ranah & $\begin{array}{l}\text { FORKAN, LPM, } \\
\text { Karang Taruna, TP- } \\
\text { PKK Nagari }\end{array}$ & $\begin{array}{l}\text { KAN Koto } \\
\text { Besar } \\
\text { Pendamping } \\
\text { Desa }\end{array}$ & TA P3MD & $\begin{array}{l}\text { Perguruan } \\
\text { Tinggi (UBH) }\end{array}$ & \\
\hline 7. & $\begin{array}{l}\text { Sungai Nyalo } \\
\text { IV Koto } \\
\text { Mudiak }\end{array}$ & $\begin{array}{l}\text { Niniak Mamak, TP } \\
\text { PKK, Pemuda } \\
\text { Nagari, } \\
\text { Pendamping Desa }\end{array}$ & $\begin{array}{l}\text { Pendamping } \\
\text { Kecamatan }\end{array}$ & TA P3MD & $\begin{array}{l}\text { Perguruan } \\
\text { Tinggi (Unes) }\end{array}$ & \\
\hline 8. & Manggopoh & $\begin{array}{l}\text { Komunitas Peduli } \\
\text { Kampuang, } \\
\text { Pemuda Nagari, } \\
\text { Dewan Mesjid }\end{array}$ & $\begin{array}{l}\text { KAN IV Koto } \\
\text { Mudiak } \\
\text { Pendamping } \\
\text { Desa }\end{array}$ & TA P3MD & $\begin{array}{l}\text { Perguruan } \\
\text { Tinggi (Unand) }\end{array}$ & $\begin{array}{l}\text { Ikatan } \\
\text { Keluarga } \\
\text { Srikandi } \\
\text { Manggopoh } \\
\text { (IKSM), }\end{array}$ \\
\hline 9. & Lubuak Jantan & $\begin{array}{l}\text { Gerakan S3 } \\
\text { (Sedekah Seribu } \\
\text { Sehari) }\end{array}$ & $\begin{array}{l}\text { Pendamping } \\
\text { Desa }\end{array}$ & TA P3MD & $\begin{array}{l}\text { Perguruan } \\
\text { Tinggi (PNP) }\end{array}$ & IWLJ dan IKLB \\
\hline
\end{tabular}

Sumber: Olahan Peneliti (2018)

Dari Tabel 5, dapat dilihat bahwa terdapat beberapa aktor komunitas yang ikut terlibat langsung dalam

penyelenggaraan pemerintahan nagari. Secara kelembagaan di tingkat nagari, terdapat LPMN, Kerapatan Adat Nagari, 
TP PKK Nagari, Karang Taruna, BKMT, Pengurus Mesjid, dan lain-lain. Para aktor memiliki peran yang berbeda dalam penyelenggaraan pemerintahan nagari sesuai dengan tugas dan fungsi dari lembaga tersebut. Selain aktor lembaga nagari tersebut, pada beberapa nagari seperti Nagari Sungayang, Nagari Koto Ranah, Nagari Sungai Nyalo IV Koto Mudiek, Nagari Manggopoh, dan Nagari Lubuak Jantan juga ditemukan community society yang berasal dari eskternal Nagari, yaitu beberapa perguruan tinggi yang melakukan kerjasama dalam pendampingan penyelenggaraan pemerintahan nagari. Pendampingan juga dilakukan oleh pendamping desa secara berjenjang, mulai dari tingkat desa, kecamatan, kabupaten dan provinsi. Pendampingan secara umum lebih banyak dalam bentuk penyampaian infrormasi-informasi terkait dengan regulasi dan kebijakan tentang penyelenggaraaan pemerintahan desa dan penyampaian laporan realisasi pemanfaatan dana desa beberapa program prioritas dari Kementerian Desa Pembangunan Daerah Tertinggal dan Transmigrasi. Peranan pendamping dirasakan masih belum optimal yang disebabkan oleh beberapa faktor, diantaranya: terbatasnya kemampuan pendamping dalam memberikan solusi dalam penyelesaian masalah di nagari, kemudian ada beberapa pendamping yang tidak berdomisili di nagari, dan aktifitas lebih banyak berupa penyampainan regulasi dan kebijakan dan penagihan laporan pelaksanaan kegiatan pembangunan nagari untuk disampaikan secara berjenjang ke pemierntahan yang lebih tinggi. Kemudian aktor community society lainnya yang cukup penting perannya perantau. Berdasarkan wawancara dengan Wali Nagari dan
Perangkat Nagari sebagian besar nagari lokus ditemukan bahwa dukungan moral dan materil serta jejaring yang diberikan oleh perantau berdampak positif terhadap kemajuan pembangunan nagari.

Perantau Nagari Sungayang yang terhimpun dalam wadah Ikatan Warga Perantauan Sungayang (IWPS) memiliki media komunikasi melalui Wathsaap Group IWPS Internasional. Demikian juga pada Nagari Lubuk Jantan dan Nagari Batu Bulek mendapatkan dukungan dari Ikatan Perantau Lintau Buo (IPLB), Nagari Padang Tarok IKPT dan Padang Tarok Center, Nagari Manggopoh (Ikatan Keluarga Srikandi Manggopoh/IKMS). Dukungan moral dan material dari para perantau sangat berpengaruh terhadap kelancaran dan kesuksesan pembangunan nagari karena para pengurus organisasi perantau umumnya adalah para tokoh-tokoh masyarakat yang disegani dan memiliki pengaruh terhadap warga nagari dan lingkup yang lebih besar. Para perantau sukses umumnya memiliki latar belakang sebagai pejabat birokrasi pemerintahan, politisi, akademisi, profesional dan pengusaha yang peduli dan telah banyak memberikan bantuan materil dan dukungan moril untuk kemajuan kampung halamannya. Namun, terdapat dua nagari yang tidak memiliki organisasi perantau yaitu Nagari Koto Tinggi dan Nagari Koto Ranah, disebabkan kedua nagari ini berasal dari Desa Unit Pemukiman Transmigrasi (UPT) pada masa orde baru, dimana penduduknya merupakan warga transmigrasi yang berasal dari Pulau Jawa dan beberapa daerah lain di Sumatera Barat yang merantau ke nagari tersebut.

Berdasarkan hasil wawancara dengan Wali Nagari dan Perangkat Nagari lokus ditemukan bahwa 
terwujudnya kolaborasi ini sangat dipengaruhi adanya keterbukaan diri dan inisiatif dari Wali Nagari dan Perangkat Nagari dalam melakukan komunikasi, koordinasi dan berkonsultasi dengan jajaran pemerintahan mulai dari tingkat kabupaten, provinsi dan pusat. Kemudian juga didukung oleh beberapa perantau yang memiliki kepedulian terhadap pembangunan nagari. Hal ini sejalan dengan apa yang menjadi temuan Hanida (2017) bahwa kolaborasi kerjasama dan hubungan antar organisasi yang disepakati bersama-sama melalui proses komunikasi. Temuan ini juga sejalan dengan Benton $(2013$; 220) menyatakan bahwa kolaborasi dalam penyediaan layanan publik yang melibatkan dua atau lebih tingkatan pemerintahan (nasional, regional, daerah dan lokal) tidak jarang terjadi kolaborasi harus dilakukan dengan berbagai cara atau strategis.

\section{Interaksi Collaborative Governance} Pada Nagari Rancak

a) Pada Tahapan Perencanaan Pembangunan dan Penyelenggaraan Nagari

Perencanaan merupakan tahap pertama dalam penyelenggaraan Pemerintahan Nagari. Pada umumnya, Nagari melaksanakan perencanaan sesuai dengan aturan Undang-Undang Nomor 6 Tahun 2014 tentang Desa. Tahap perencanaan dilakukan dengan pendekatan partisipatif melalui forum musyawarah nagari dan musyawarah perencanaan pembangunan nagari. Dokumen yang dihasilkan dari siklus perencanaan pembangunan nagari adalah dokumen Rencana Pembangunan Jangka Menengah (RPJM) Nagari dan Rencana Kerja Pembangunan (RKP) Nagari. RKP Nagari dijadikan dasar penetapan Anggaran Pendapatan dan Belanja Nagari (APB Nagari). Untuk menyusun dan menetapkan dokumen tersebut, telah dilakukan musyawarah mulai dari tingkat Jorong/Kampung. Musyawarah ini dilakukan untuk mendata kebutuhan masyarakat yang akan dihimpun menjadi prioritas pembangunan nagari melalui Musyawarah Nagari.

Secara umum, setiap Nagari lokus telah melaksanakan kegiatan perencanaan pembangunan sesuai tahapan dan jangka waktu yang ditetapkan. Selain untuk membahas rencana pembangunan, Musyawarah Nagari juga dimaksudkan untuk membuat produk hukum Nagari. Contohnya di Nagari Manggopoh yang membuat regulasi lebih maju, dimana semua kewenangan nagari yang diatur dalam UU Desa diterapkan di Nagari ini. Hal yang sama juga ditemukan di Nagari Sungayang, dalam perencanaan pembangunan nagari maupun pengambilan keputusan dalam perencanaan dan penyelesaian masalahmasalah nagari, dilibatkan semua unsur yang ada di nagari termasuk Ninik Mamak dan Perantau. Musyawarah dilaksanakan pada Balai-Balai Adat Nagari Sungayang. Setelah disusun, dilaporkan kepada BPRN. Jika disetujui BPRN, diserahkan kepada bidang masing-masing di Pemerintah Nagari untuk pembuatan RAPB Nagari. Rancangan yang dibuat oleh masingmasing bidang kemudian disatukan dan dirangkum oleh Sekretaris Nagari, lalu diserahkan kepada BPRN. Selanjutnya BPRN yang akan menyerahkan kepada Camat untuk disampaikan kepada Bupati. Pada tahap perencanaan, semua aktor yang terlibat saling berinteraksi baik dalam forum musyawarah nagari, maupun setelah dokumen disusun. Dalam forum musyawarah nagari, pemerintah, swasta, dan masyarakat diundang dan hadir berasama dalam membuat keputusan 
yang dapat mendukung penyelenggaraaan pemerintahan nagari.

b) Pada Tahapan Penganggaran Pembangunan dan Penyelenggaraan Pemerintahan Nagari

Tahap penganggaran merupakan tahapan dimana perencanaan yang telah disepakati berasama dalam bentuk RKP Nagari dijabarkan dalam bentuk anggaran berupa APB Nagari. Rancangan APB Nagari harus disepakati oleh Wali Nagari bersama dengan Bamus/BPRN/BPN, dan disampaikan kepada Bupati melalui Camat untuk dievaluasi. Untuk tahap penganggaran, disemua nagari lokus telah menyiapkan APBNagari sesuai ketentuan yang berlaku yang berasal dari RKP yang telah disusun sebelumnya. Keterlibatan aktor governance dalam tahapan penganggaran tidak se-intensif pada tahapan perencanaan dikarenakan proses penganggaran lebih dominan menggunakan pendekatan teknokratik, termasuk pemanfaatan aplikasi SISKEUDES yang dilaksanakan oleh operator dan sekretaris nagari. Hal yang cukup menarik terkait interaksi stakehoder pada tahapan penganggaran ditemukan di Nagari Batu Bulek, dimana DPRD Kabupaten dan DPRD Provinsi yang berasal dari Nagari Batu Bulek mengalokasikan pokok-pokok pikiran melalui bantuan keuangan bersifat khusus yang menjadi sumber penerimaan dalam APB Nagari. Seluruh nagari lokus telah menyusun dan menetapkan dokumen APB Nagari sesuai aturan dan pada jangka waktu yang ditentukan.

c) Pada Tahapan Pelaksanaan Pembangunan dan Penyelenggaraan Nagari

Secara keseluruhan, setiap Nagari melaksanakan pembangunan dengan prinsip partisipatif. Di Nagari Manggopoh, sebelum pembangunan dilaksanakan, dilakukan musyawarah pra pelaksanaan. Musyawarah dilaksanakan setelah dana dicairkan. Dalam pelaksanaan, perantau ikut membina masyarakat agar tidak merantau. Hal ini ditujukan supaya pemuda Nagari dapat membangun Nagari. Sedangkan Nagari Sungai Nyalo IV Koto Mudiek, pelaksanaan pembangunan dilakukan dengan gotong royong. Masyarakat rela menyumbangkan tanahnya tanpa ganti rugi untuk membangun akses jalan dan pembangunan infrastruktur lainnya. Pelaksana pembangunan tersebut melibatkan masyarakat Jorong yang bersangkutan.

Lain halnya dengan Nagari Lubuak Jantan, untuk melaksanakan pembangunan, perantau berpartisipasi dalam bentuk dukungan ide, gagasan, dan materi. Contohnya untuk pemugaran Mesjid Raya Nagari Lubuk Jantan, perantau menyanggupi untuk menyumbang sebesar Rp. 6 milliar. Hal yang sama sudah terlaksana di Nagari Sungayang, dimana untuk pembangunan Mesjid Raya Sungayang yang runtuh akibat gempa bumi tahun 2009, dibangun kembali dari awal pada tahun 2010-2015 dan menghabiskan anggaran sebesar Rp. 5 Milyar sebagian besar berasal dari sumbangan perantau. Di Juga Nagari Lubuk Jantan ada yang unik dimana Perantau menyewakan alat berat untuk pembangunan jalan di nagari, dikarenakan dana desa tidak dibolehkan untuk sewa alat berat dan harus diutaman untuk padat karya tunai. Sementara ada kegiatan pembangunan jalan yang tidak sanggup dilakukan oleh tenaga manusia sepenuhnya.

Hampir sama dengan Nagari Lubuak Jantan, di Nagari Batu Bulek masyarakat aktif berswadaya untuk pembangunan nagari, berbentuk 
menyerahkan tanah tanpa ganti rugi, ikut bekerja dan menyumbangkan tenaga melalui gotong royong, dan kaum ibu menyediakan konsumsi yaitu membawa "nasi kucuik". Upah padat karya tunai sebagian disumbangkan kembali untuk menambah pembelian material dalam pembangunan nagari, sehingga nilai proyek yang dilaksanakan dapat melebihi dua kali lipat dari jumlah anggaran yang disediakan. Kerjasama antar jorong bahkan antar nagari juga telah dilaksanakan dalam pembangunan seperti dalam penyelesaian masalah aliran batang air yang bermasalah. Sedangkan di Nagari Sungayang, untuk melaksanakan pembangunan dibentuk Tim Pelaksana Kegiatan (TPK). TPK dipilih dengan cara musyawarah. Pelaksanaan dilakukan dengan gotong royong. Setelah kegiatan selesai, dibentuk tim pemanfaat kegiatan untuk mengontrol manfaat dari kegiatan.

\section{d) Pada Tahapan Pengawasan Pembangunan dan Penyelenggaraan Pembangunan Nagari}

Pada tahap pengawasan, masyarakat melaksanakannya bersama dengan Bamus dan kelompok masyarakat yang ada di Nagari. Di Nagari Koto Ranah, dilaksanakan apel mingguan. Apel mingguan ini diikuti oleh Pemerintah Nagari, Bamus, LPM, Karang Taruna, FORKAN, BUMNag, TP-PKK, dilanjutkan rapat koordinasi untuk membahas berbagai persoalan pemerintahan sebagai evaluasi mingguan penyelenganggaraan pemerintahan nagari. Di Nagari Manggopoh, evaluasi pelaksanaan dilakukan setiap hari senin dan jumat. Di Nagari Sungayang, dilaksanakan pertemuan setiap bulan. Pertemuan ini dilaksanakan bersama dengan masyarakat, tujuannya supaya masyarakat dapat memberikan masukan, tanggapan, informasi, dan sesuatu hal yang dianggap perlu.

Cara yang sedikit berbeda dilakukan oleh Wali Nagari Koto Tinggi, dimana Wali Nagari dan perangkat nagari menyusun agenda rapat bulanan dengan seluruh lembaga di nagari, namun pelaksana dan tempat acara adalah lembaga tersebut, dan wali nagari bersama perangkat nagari berkunjung ke kantor lembaga tersebut. Cara ini memilik hal yang positif untuk mendorong lembaga-lembaga nagari lebih siap melaksanakan tugas dan fungsinya serta aktif melakukan konsolidasi secara internal di lembaga. Di Banyak nagari sering ditemukan lembaga-lembaga nagari tidak aktif sebagaimana mestinya, dan pengurus lembaga yang aktif hanya beberapa orang saja. Hal ini merupakan salah satu bentuk pengawasan dan pembinaan oleh pemerintah nagari terhadap lembaga-lembaga nagari dalam melaksanakan berbagai program dan kegiatan pembangunan di nagari.

Sebagai salah satu bentuk nyata adanya transparansi dan untuk memudahkan semua orang bisa mengawasi penyelenggaraaan pemerintahan nagari maka semua nagari lokus telah membuat Ringkasan APBNagari dalam bentuk baliho yang dipasang pada beberapa tempat strategis di nagari agar mudah dilihat dan diketahui oleh masyarakat atau pihakpihak yang memerlukan informasi tersebut. Di seluruh nagari lokus juga menyebarkan informasi APB Nagari ada dengan memasang iklan di media cetak dan website nagari, akun facebook, instagram wathsapp group. 
e) Pada

Tahapan

Pertanggungjawaban Pembangunan dan Penyelenggaraan Pembangunan Nagari

Pada tahap pertanggungjawaban, Pemerintah Nagari telah membuat Laporan Penyelenggaraan Pemerintahan Nagari (LPPN) dan Laporan Keterangan Pertanggungjawaban (LKPj). Laporan tersebut disampaikan oleh pemerintah Nagari kepada Bamus Nagari, untuk kemudian dinilai penyelenggaraan pemerintahan selama satu tahun, maupun diakhir periode wali nagari. Pada tahapan ini, aktor governance yang dominan terlibat adalah Bamus/BPRN/BPN sesuai dengan tugas pokok dan fungsinya, Camat serta OPD terkait di tingkat Kabupaten seperti Dinas Pemberdayaan Masyarakat Desa/Nagari, Badan Pengelola Keuangan Daerah dan Inspektorat Kabupaten.

\section{Keberhasilan Collaborative}

\section{Governance Pada Nagari Rancak}

Untuk mengukur keberhasilan collaborative governance pada penelitian ini, digunakan 8 (delapan) indikator untuk menggambarkan tingkat keberhasilan collaborative governance pada 9 (sembilan) Nagari Rancak di Sumatera Barat yang menjadi lokus penelitian.

\section{a) Network Structure}

Dalam penyelenggaraan

Pemerintahan Nagari, setiap elemen yang ada di Nagari saling berkaitan, dan tidak membentuk hierarkhi. Di Nagari Sungayang, untuk melaksanakan pembangunan, dilibatkan semua unsur yang ada di Nagari. Perencanaan dilakukan dengan cara musyawarah. Pelaksanaan juga melibatkan perantau, dan kelompok masyarakat. Begitu juga di Nagari Koto Tinggi dimana setiap stakeholder memiliki tugas dan fungsi masing-masing. Untuk dapat bersinergi, dilaksanakan pertemuan satu bulan sekali. Setiap kegiatan yang dilaksanakan melibatkan semua unsur yang ada di Nagari.

Setiap unsur di Nagari saling bersinergi untuk melaksanakan kegiatan. Di Nagari Koto Tinggi, pemerintah membuat kebijakan untuk menanam pohon sebagai syarat untuk menikah. Masyarakat yang akan menikah mengikuti aturan tersebut, dan pohon yang ditanam berasal dari PT BBS, sebagai penyalur tanaman. Tujuannya adalah untuk pelestarian ekologi Nagari. Jika pemerintah, masyarakat, dan swasta tidak saling berkaitan, tujuan pembangunan akan memihak, dan akan menimbulkan hierarkhi dalam penyelenggaraan pemerintahan. Pelestarian ekologi Nagari juga dilakukan di Nagari Koto Ranah, dimana Nagari ini bekerja sama dengan PT Perkebunan Kelapa Sawit Nasional (PT Incasi Raya Group PT SMP), dan membuka koperasi kelapa sawit.

Sedangkan di Nagari Sungai Nyalo IV Koto Mudiek, untuk melaksanakan pembangunan dilakukan dengan gotong royong. Selain itu, untuk pembangunan fisik, pekerjanya dari masyarakat yang berada di sekitar. Hal ini juga berfungsi untuk menambah penghasilan masyarakat yang bekerja serabutan. Kegiatan di beberapa Nagari seperti yang dijabarkan di atas, dilaksanakan atas dasar kerja sama dan setiap unsur yang ada di Nagari saling berkaitan satu sama lain dalam membangun Nagari. Hal ini tentunya menguntungkan untuk memajukan Nagari.

\section{b) Commitmen to a Common}

Purpose

Merupakan perhatian atau komitmen untuk mencapai tujuan bersama. Pemerintah, masyarakat dan 
swasta sama-sama berinteraksi dan membuat komitmen bersama untuk mencapai tujuan. Pemerintah merupakan pembuat kebijakan dan penyedia layanan, swasta berfungsi untuk meningkatkan perekonomian nagari, sedangkan masyarakat merupakan subjek yang ikut terlibat aktif dalam setiap tahapan, dan pengawas setiap kegiatan yang dilaksanakan. Dengan adanya komitmen pada pencapaian tujuan bersama, dan dilaksanakan secara sadar dan terstruktur, tujuan dapat tercapai. Di Nagari Manggopoh, masyarakat terlibat dalam proses pra pelaksanaan pembangunan, dan melakukan evaluasi setiap senin dan jumat. Dalam pelaksanaan pembangunan Jalan, dilakukan kerjasama dengan PT KAMU, yaitu penyediaan alat berat. Terlihat jelas bahwa pemerintahan nagari, masyarakat, dan swasta telah membuat komitmen bersama untuk pembangunan, dan bersama-sama berkomitmen untuk melaksanakannya. Output yang didapatkan yaitu jalan yang dibangun dapat diselesaikan tanpa adanya konflik dan tidak memakan biaya yang cukup besar.

Sedangkan di Nagari Koto Ranah, hubungan antar lembaga dibangun melalui media apel mingguan dan bulanan. Pembina apel bergantian antara Wali Nagari, dan Pimpinan LembagaLembaga Tingkat Nagari, termasuk Sekretaris Nagari. Adanya kesediaan semua pihak untuk menghadiri apel dan rapat monitoring dan evaluasi serta rapat koordinasi secara rutin setiap minggu dan setiap bulan memberikan indikasi adanya komitmen bersama dalam pembangunan nagari di Nagari Koto Ranah.

Hampir sama dengan Nagari Koto Ranah, Nagari Lubuk Jantan yang mengoptimalkan peran Tungku Tigo Sajarangan yang bekerjasama dalam pelaksanaan pembangunan dan bekerja secara bersama-sama untuk menyelesaikan persoalan dalam penyelenggaraan pemerintahan nagari. Dalam menyusun berbagai bentuk regulasi yang akan membebankan masyarakat serta perencanaan pembangunan nagari yang akan membutuhkan partisipasi masyarakat, ternyata setelah dilakukan msuyawarah oleh lembaga tungku tigo sajarangang, terutama ninik mamak dan alim ulama, selalu mendapatkan dukungan dari masyarakat nagari. Hal ini ditujukan supaya tujuan (memandirikan Nagari) dapat tercapai. Selaras dengan hal tersebut, di Nagari Batu bulek, setiap stakeholder berkomitmen untuk melaksanakan tugas dan fungsi masingmasing.

\section{c) Trust Among The Participant}

Mempercayakan informasi kepada stakeholder dalam suatu jaringan. Dalam penyelenggaraan pemerintahan Nagari, Pemerintah wajib menerapkan prinsip transparansi. Di Nagari Batu Bulek, Pemerintah Nagari menyampaikan informasi melalui mesjid yang ada di setiap jorong oleh kepada jorong, informasi terkait dengan rencana pembangunan, pelayanan masyarakat, pengawasan dan pertangungjawaban kegiatan. Nagari Batu Bulek memiliki sebanyak 12 mesjid, termasuk mesjid nagari. Hal yang sama juga dilakukan di Nagari Sungai Nyalo IV Koto Mudiek. Nagari ini menyampaikan informasi lewat mesjid dan lewat tokoh-tokoh masyarakat. Sedangkan di Nagari Palaluar, Mulai dari tahapan perencanaan pembangunan lembaga-lembaga seperti KAN, BPN, LPM, Pemuda dan tokoh masyarakat telah dilibatkan dalam pengambilan keputusan, sehingga semua elemen masyarakat kompak dalam 
melaksanakan pembangunan, termasuk dalam menangkap setiap peluang pembangunan yang berasal dari pemerintahan tingkat atas. Setiap informasi yang ada pada masing-masing tahap diberikan kepada stakeholder. Di Nagari Manggopoh, informasi akan diberikan lewat sosialisasi, dan informasi dapat diakses pada masing-masing jorong.

Nagari Sungayang memiliki cara yang unik dalam membangun partisipasi terkait dengan bagaimana mengelola infromasi. Pemerintahan Nagari Sungayang menggunakan media online yaitu Watsaap Group WPS Internasional, dimana setiap rencana dan pelaksanaan kegiatan pembangunan nagari diinformasikan melalui watsaap sehingga bisa diketuhui pula oleh anak nagari yang merantau baik di dalam negeri maupun di luar negeri. Cara ini cukup efektif dan dapat meningkat kepercayaan perantau terhadap penyelenggaraan pemerintahan nagari. Dengan mempercayakan informasi kepada stakeholder, Pemerintah Nagari akan lebih transparan dan mendapatkan umpan balik berupa meningkatnya kepercayaan dari para stakeholder.

\section{d) Governance}

Hubungan saling percaya, adanya aturan yang disepakati bersama, dan adanya kebebasan menentukan bagaimana kolaborasi diinginkan. Di Nagari Sungai Nyalo IV Koto Mudiek, Pemerintah, Masyarakat, dan Swasta sama-sama berinteraksi dan menyusun perencanaan melalui musyawarah, lalu dilaksanakan dengan cara berkolaborasi. Di Nagari Manggopoh pengelolaan fee nagari yang diberikan langsung kepada KAN dan tidak menjadi sumber pendapatan nagari yang tertuang dalam APB Nagari merupakan salah satu bentuk kesepakatan antar aktor dalam berkolaborasi, dikarenakan adanya keterbatasan aturan yang mengatur bentuk penggunaan dana yang berasal dari swasta baik dalam sistem akuntansi perusahaan maupun akuntansi pemerintahan.

Demikian juga dalam pelaksanaan CSR Perusahaan Perkebunan kelapa sawit untuk pembangunan nagari Koto Tinggi dan Nagari Koto Ranah yang juga disepakati pelaksanaannya melalui gotong royong tidak kontraktual sehingga bisa melibatkan partisipasi masyarakat. Kesepakatan yang sama juga dilakukan di Nagari Batu Bulek, dimana anggota DPRD bersepakat bahwa pelaksanaan pokok-pokok pikiran dilakukan melalui pola bantuan keuangan besifat khusus yang dimasukan dalam APB Nagari, sehingga perencanaan dan pelaksanaan dan pengawasannya dapat dilakukan secara bersama antara anggota DPRD dan Pemerintahan Nagari.

Nagari Lubuk Jantan, Nagari Padang Tarok dan Nagari Manggopoh juga membuat kesepakatan berkolaborasi dengan komunitas yang peduli terhadap pemberian santunan kepada keluarga yang kurang mampu, dimana pemerintahan nagari memiliki keterbatasna kewenangan dan anggaran, maka disepakati dikelola oleh komunitas yang menghimpun dana yang sebagian besar dari para perantau dan disalurkan berdasarkan rekomendasi dari pemerintahan nagari agar tidak terjadi tumpang tindih sasaran dalam penyalurannya.

Dari uraian tersebut diatas terlihat bahwa pada nagari lokus, stakeholder telah diberikan kebebasan untuk menentukan kolaborasi yang akan dijalankan dalam forum musyawarah 
nagari, dan sesuai dengan dasar hukum yang berlaku.

\section{e) Access to authority}

Ketersediaan ukuran-ukuran, ketentuan prosedur-prosedur yang jelas dan diterima secara luas. Masing-masing stakeholder menjalankan sesuai dengan peran dan kewenangannya. Pada setiap Nagari Rancak, di Kantor Wali Nagari ditempelkan syarat-syarat pelayanan umum kepada masyarakat. Di Nagari Sungai Nyalo IV Koto Mudiek, juga ditempel banner "pelayanan secepatnya". Artinya, jika persyaratan cukup, pelayanan akan diberikan secepatnya, kurang dari satu hari.

\section{f) Distributive accountability dan responsibility}

Penataan, pengelolaan, manajemen secara bersama-sama dengan stakeholder dan berbagi sejumlah pembuatan keputusan kepada seluruh anggota jaringan serta berbagi tanggung jawab untuk mencapai hasil yang diinginkan. Dalam pengambilan keputusan, masingmasing Nagari Rancak telah melakukan musyawarah. Di Nagari Koto Tinggi, dilaksanakan musyawarah mingguan, bulanan, dan triwulan. Musyawarah mingguan dilakukan oleh perangkat nagari. Untuk bulanan Pemerintah Nagari bersama dengan Bamus. Sedangkan untuk triwulan, semua stakeholder yang ada di nagari ikut terlibat dalam musyawarah. Di Nagari Manggopoh, setelah APB Nagari bisa dicairkan, dilakukan musyawarah pra pelaksanaan dan pembentukan tim pelaksana. Hal yang sama juga dilakukan di Nagari Koto Ranah, dimana musyawarah dilaksanakan setiap minggu dan setiap bulan untuk membahas permasalahan di Nagari. Pembagian tugas dalam pengambilan keputusan lebih menonjol pada tahapan pelaksanaan kegiatan dengan dibentuknya
Tim Pelaksana Kegiatan (TPK) Pembangunan Nagari yang dipimpin oleh Perangkat Nagari dan beranggotakan unsur masyarakat yang ada di Jorong masing-masing. Keputusan-keputusan yang bersifat teknis sepenuhnya menjadi kewenangan dari TPK masing-masing kegiatan, sampai dengan proses pertanggung jawaban dan pelaporan pelaksanaan kegiatan pembangunan nagari.

\section{g) Information Sharing}

Kemudahan akses bagi para anggota, perlindungan privasi, dan keterbatasan akses bagi yang bukan anggota selama bisa diterima semua pihak. Setiap Nagari memiliki website Nagari untuk dapat menyebarkan informasi terkait Nagari. Namun, pada beberapa Nagari seperti Nagari Sungai Nyalo IV Koto Mudiek, Nagari Palaluar, Nagari Padang Tarok, dan Nagari Lubuak Jantan, dan Nagari Koto Ranah telah mengembangkan website Nagari, namun tidak diperbaharui informasi didalamnya. Hal ini dikarenakan Sumber Daya Manusia (SDM) yang akan melaksanakan tidak ada atau tidak kompeten. Namun, Nagari-Nagari tersebut telah berupaya untuk meningkatkan kualitas penyampaian informasi. Untuk informasi yang dianggap sensitif, seperti keuangan Nagari, jika ingin mendapatkan informasi tersebut, stakeholder harus mendatangi kantor Wali Nagari secara langsung.

Pada Nagari Manggopoh, Nagari Koto Ranah dan Nagari Koto Tinggi pengelolaan informasi penyelenggaraan pemerintahan nagari banyak dilakukan melalui media sosial dalam bentuk laman facebok dan instagram, yang selalu diupdate setiap waktu. Sedangkan di Nagari Sungayang komunikasi lebih banyak menggunakan wathsaap, salah satu bentuknya adalah Watsaap Group 
Warga Sungayang Perantauan Internasional yang dijadikan sebagai media komunikasi dan informasi antara pemerintahan nagari dengan lembagalembaga nagari serta para perantau di luar nagari.

\section{h) Access to resources}

Ketersediaan sumber keuangan, teknis, manusia, dan sumber daya lainnya yang diperlukan untuk mencapai tujuan. Untuk sumber keuangan, masing-masing Nagari mendapatkan Dana Desa dan Alokasi Dana Desa. untuk menambah pemasukan Nagari, setiap Nagari memiliki Pendapatan Asli Nagari (PAD). PAD berasal dari potensi Nagari. Untuk memaksimalkan potensi Nagari, setiap Nagari memiliki Bumnag. Di Nagari Koto Ranah, BUMNag Koto Ranah Sakti memiliki unit usaha yaitu pariwisata dan perikanan dengan memanfaatkan embung koto ranah yaitu budidaya ikan dan kebun binatang yang menjadi salah satu unggulannya adalah penangkaran buaya. Sedangkan di Nagari Padang Tarok, Bumnag baru terbentuk dan bergerak di bidang pertanian, pupuk, LPHN, pariwisata. Untuk Nagari Batu Bulek, Bumnag bergerak pada bidang Pamsimas, Penyewaan Hand Traktor dan Pengelolaan Objek Wisata Puncak Pato. Selanjutnya di Nagari Koto Tinggi Bumnag bergerak di bidang Grosir Minyak goreng, budidaya sapi bali, sistem bagi hasil dengan warga. Lalu di Nagari Sungai Nyalo IV Koto Mudiek, Bumnag bergerak di bidang simpan pinjam. Yang terakhir di Nagari Paluar, Bumnag bergerak di Bidang Jasa keuangan, Pertanian, dan Pengelolaan Pasar Nagari. Untuk Ketersediaan sumber daya teknis, manusia, dan sumber daya lainnya, setiap nagari memiliki potensi sumber daya manusia. Namun, hal yang perlu ditekankan adalah untuk membuat sumber daya tersebut bisa kompeten pada suatu bidang dan dapat memajukan Nagari.

Sejalan dengan perkembangan regulasi dalam penyelenggaraan pemerintahan nagari serta tuntutan pelaksanaan tugas menggunakan teknologi informasi, maka berdasarkan observasi peneliti ditemukan bahwa kualitas sumber daya manusia perangkat nagari menjadi salah satu tantangan dalam penyelenggaraan pemerintahan nagari. Namun, dengan seringnya dilakukan pelatihan-pelatihan oleh pemerintah daerah dan pemerintah pusat serta pelatihan yang dilakukan sendiri oleh pemerintahan nagari telah berdampak terhadap peningkatan komptensi perangkat nagari sebagai aktor utama dalam pelaksanaan kegiatan di nagari. Secara umum perangkat nagari dan pengurus-pengurus lembaga-lembaga di nagari lokus sudah didominasi oleh generasi muda yang memiliki kualifikasi pendidikan minimal SLTA dan bahkan di beberapa nagari sudah berpendidikan Diploma dan Sarjana.

Sumber daya lainnya yang bersifat intagible (tidak terlihat) adalah jejaring dan networking yang dimiliki oleh pemerintahan nagari. Sejalan dengan hasil penelitian Putri (2019), jejaring ini umumnya berasal dari para perantau, anak nagari yang menduduki jabatan di pemerintahan seperti pejabat pemerintah daerah dan pusat serta anggota DPRD, dari Perguruan Tinggi dan lembagalembaga yang peduli dengan pembangunan nagari. Berbagai peluang dan informasi untuk pembangunan nagari didapatkan melalui jejaring dan networking yang dimiliki oleh pemerintahan nagari.

Berdasarkan wawancara dengan informan dan penelusuran terhadap 
berbagai bentuk keberhasilan dan prestasi nagari rancak, maka dapat disimpulkan bahwa keberhasilan dalam mewujdukan kolaborasi dalam penyelenggaraan pemerintahan nagari diawali oleh adanya rasa memiliki nagari yang tinggi dari anak nagari dan kemudian didukung oleh hadirnya kepemimpinan wali nagari yang visioner dalam memajukan nagari serta mau membuka diri untuk bekerjasama dengan semua stakeholder. Nilai-nilai kebersamaan dan kepemimpinan visioner tersebut melahirkan hubungan kerjasama yang harmonis antara pemerintah nagari dengan stakeholder di tingkat nagari, kecamatan, kabupaten, bahkan sampai ke tingakat provinsi dan nasional.

\section{KESIMPULAN}

Berdasarkan hasil penelitian dapat disimpulkan. Pertama, profil nagari rancak secara umumnya adalah nagari berbasis sektor pertanian, yang telah meraih banyak prestasi sebelum menjadi juara lomba nagari rancak di tingkat kabupaten dan provinsi. Kedua, kolaborasi aktor governance terjadi pada setiap tahapan penyelenggaraan pemerintahan yaitu perencanaan, penganggaran, pelaksanaan, perngawasan dan pertanggung jawaban. Interaksi aktor yang paling intensif pada tahapan perencanaan dan pelaksanaan program dan kegiatan di tingkat nagari. Ketiga, keberhasilan kolaborasi dapat dilihat dari delapan indikator menurut Goldsmith dan Kettl (2009) karena adanya rasa memiliki nagari yang tinggi dari anak nagari serta adanya kepemimpinan wali nagari yang visioner dalam memajukan nagari dan mau membuka diri untuk bekerjasama dengan semua stakeholder, ternasuk dengan perantau. Nilai-nilai kebersamaan dan kepemimpinan tersebut melahirkan hubungan kerjasama yang harmonis antara pemerintah nagari dengan stakeholder di tingkat nagari, kecamatan, kabupaten, bahkan sampai ke tingkat provinsi dan nasional.

Model collaborative governance dapat diterapkan pada semua nagari (desa) meskipun memiliki karakteristik potensi yang berbeda-beda. Rasa banagari menjadi modal sosial yang dapat dimanfaatkan untuk memajukan nagari. Oleh karena itu bagaimana mewujudkan hubungan kerja yang harmonis antara pemerintahan nagari dengan stakeholder menjadi factor utama terwujudnya tata kelola pemerintahan nagari rancak di Provinsi Sumatera Barat. Penguatan kapasitas kepemimpinan wali nagari juga sangat penting, karena kepemimpinan yang visioner dan kemauan membuka diri untuk bekerjasama dalam memajukan nagari menjadi prasyarat terwujudnya model collaborative governance dalam penyelenggaraan pemerintahan nagari. Kontribusi hasil penelitian ini yaitu menemukan bahwa aspek rasa banagari, kepemimpinan visioner dan terbuka menjadi kata kunci dalam berkolaborasi. Temuan ini diharapkan dapat memperkaya kajian-kajian kepemimpinan collaborative terutama pada pemerintahan lokal.

\section{REKOMENDASI}

Berdasarkan temuan hasil penelitian, dapat direkomendasikan saran sebagai berikut: pertama, saran praktis, pembinaan pemerintahan nagari oleh pemerintahan tingkat atas (kecamatan, kabupaten/kota, provinsi dan pusat) agar lebih difokuskan kepada penguatan kapasitas kepemimpinan collaborative wali nagari terutama terkait dengan bagaimana menjaga harmonisasi hubungan kerja antar lembaga di tingkat nagari dan bagaimana membangun 
jejaring (networking) dengan semua stakeholder pemerintahan nagari baik di tingkat nagari, kecamatan, kabupaten/kota, provinsi maupun nasional bahkan internasional. Kedua, aspek kepemimpinan wali nagari memegang peranan penting dalam berkolaborasi. Oleh karena itu penelitian selanjutnya untuk mendalami temuan penelitian ini dapat dilihat dari aspek atau dimensi-dimensi kepemimpinan dikaitkan

\section{DAFTAR PUSTAKA}

Afful-Koomson dan Kwabena (2013), Collaborative Governance in Extractive Industries in Africa. Africa: Pixedit Limited.

Ansell dan Alison (2007), Collabotaive Governance in Theory and Practice. Journal of Public Administration Research and Theory, November 13,p.543-570.

Benton, J. Edwin (2013), Local Government Collaboration: Considerations, Issues, and Prospects. State and Local Government Review Vol. 45 (4).p. 220-223.

Bungin, Burhan (2007), Penelitian Kualitatif: Komunikasi, Ekonomi, Kebijakan Publik dan Ilmu Sosial lainnya. Kencana Pranada Media Group: Jakarta.

Ghozali, Imam (2006), Aplikasi Analisis Multivariate dengan Program SPSS (Edisi Ke 4). Badan Penerbit Universitas Diponegoro: Semarang.

Hanida, Rozidateno Putri, Bimbi Irawan, Syamsurizaldi, Wewen Kusumi Rahayu (2017), Collaboration of Stakeholders In Formation and Development Nagari-Owned model collaborative governance pada nagari rancak atau nagari secara umum di Provinsi Sumatera Barat atau Desa di seluruh Indonesia. Dimensi kepemimpinan lokal cukup menarik untuk dikaji dalam konteks penyelenggaraan pemerintahan di Indonesia yang sangat kaya dengan keanekaragaman suku, budaya dan agama.

Enterprise. Policy \& Governance Review. Vol.1, Issue 3, p.213-227.

Koiman, Jan (2008), Governing in Governance, Sage Publication.

Kurniawan, Teguh (2009), Peranan Akuntabilitas Publik dan Partisipasi Masyarakat dalam Pemberantasan Korupsi di Pemerintahan. Jurnal Ilmu Administrasi dan Organisasi, Vol. 16 (2), p. 116-117.

Lexy Moleong (1998), Metode Penelitian Kualitatif. Bandung: Remaja Rosda Karya

Malau, Hasbullah (2013), Implementasi Good Governance Pada Pemerintahan Nagari di Sumatera Barat, Jurnal TINGKAP Vol. IX (2).p.126-140.

Peraturan Daerah Provinsi Sumatera Barat Nomor 7 Tahun 2007 tentang Pemerintahan Nagari

PP Nomor 43 tahun 2014 tentang Peraturan Pelaksanaan UU Nomor 6 tahun 2014.

Putri, Annisa Aulia Ria Ariany dan Syamsurizaldi (2019), Sistem Tata Kelola Pemerintahan Nagari Dalam Menciptakan Public Value di Nagari Sungai Nyalo IV Koto 
Mudiak, Kecamatan Batang Kapas Kabupaten Pesisir Selatan. Publicia: Jurnal Ilmu Administrasi Publik, Vol.4 (1). P.102-116.

Putri, Annisa Aulia (2019), Partisipasi Perantau: Basamo Membangun Nagari di Nagari Sungai Pua Kabupaten Agam. Jurnal Administrasi dan Kebijakan Publik, Vol. 4 (1), p. 42-54.

Rahmawati, Ahfan, Asrori, dan Hotnier Sipahutar (2015), Implikasi Juara Lomba Desa Pada Perkembangan Desa.Jurnal Bina Praja Vol. 7 (4) p.297-306.

Sedarmayanti (2004), Sumberdaya Manusia dan Produktivitas Kerja.Mandar Maju:Bandung.

Strauss, Anselm dan Corbin, Juliet (1990), Grounded Theory Research: Prosedures, Canons, and Evaluation Criteria. Qualitative Sociology Journal, Vol. 13 (1), p. 3-21.
Sumarto dan Hetifah (2003), Inovasi, Partisipasi dan Good Governance-20 Prakarsa Inovatif dan Partisipatif di Indonesia. Yayasan Obor Indonesia.

Syamsurizaldi (2012), Format Ideal Penyelenggaraan Pemerintahan Nagari di Provinsi Sumatera Barat.Jurnal Pamong Praja-DPN IKAPTK, Vol. 1 (1).p.

Syamsurizaldi, Annisa Aulia Putri, Suherdian Antoni dan Rozidateno Putri Hanida (2018), Dampak Perkembangan Sumber Keuangan Nagari Terhadap Inovasi Perencanaan dan Penganggaran Program dan Kegiatan Pembangunan Nagari di Kabupaten Solok Selatan Tahun 2013-2016.Jurnal Pembangunan Nagari Vol. 3 (1). P.75 - 96.

UU Nomor 6 Tahun 2014 Tentang Desa 